Artikel Penelitian

\title{
Performa Rapid Emergency Medicine Score dalam Memprediksi Outcome Pasien Trauma Kepala di Instalasi Gawat Darurat
}

\section{Validation of Rapid Emergency Medicine Score in Predicting the Outcome of Head Injury Patient in the Emergency Department}

\author{
Didik Mulyono, Nurdiana, Rinik Eko Kapti \\ Program Studi Magister Keperawatan Fakultas Kedokteran Universitas Brawijaya Malang \\ Departemen Farmakologi Fakultas Kedokteran Universitas Brawijaya Malang \\ Departemen Keperawatan Fakultas Kedokteran Universitas Brawijaya Malang
}

\begin{abstract}
ABSTRAK
Rapid Emergency Medicine Score (REMS) merupakan suatu sistem skor yang telah digunakan secara luas di berbagai negara untuk memprediksi mortalitas pasien non bedah maupun trauma di Instalasi Gawat Darurat (IGD), tetapi belum diuji pada populasi yang spesifik pada trauma kepala. Tujuan penelitian ini untuk menilai performa REMS dalam memprediksi outcome pasien trauma kepala di IGD. Penelitian ini menggunakan desain observasi analitik dengan pendekatan retrospektif. Sampel menggunakan data rekam medis pasien dengan trauma kepala sedang-berat disesuaikan dengan kriteria inklusi dan eksklusi dan digunakan teknik purposive sampling yaitu sebanyak 181 responden. Analisis bivariat yang dilakukan pada penelitian ini menggunakan uji Somers'd, sedangkan analisis multivariat menggunakan regresi logistik ordinal. Selanjutnya, kemampuan untuk memprediksi outcome dinilai menggunakan analisis the area under the receiver operating characteristic (AUROC). Hasil uji bivariat menunjukkan bahwa nilai somers'd REMS sebesar 0,310 dengan $p$ value $<0,001$ dan arah hubungan positif dengan outcome pasien trauma kepala. Hasil regresi logistik ordinal menunjukkan parameter Glasgow Coma Scale (GCS) memperoleh Odds Ratio sebesar 0,7, artinya skor GCS yang rendah memiliki risiko memperoleh outcome death sebesar 0,7 kali lebih besar dibandingkan memperoleh outcome moderate disability, severe disability, persisten vegetatif state. Nilai Area Under Curve (AUC) REMS pada cut of point $>5$ dengan sensitivitas 61,4 dan spesifisitas 77,8 adalah 0,753 ( $95 \% \mathrm{Cl}$; 0,683-0,814. REMS menunjukkan performa yang baik dalam memprediksi outcome pasien trauma kepala.
\end{abstract}

Kata Kunci: IGD, outcome, REMS, trauma kepala

ABSTRACT

The Rapid Emergency Medicine Score (REMS) is a scoring system that has been used extensively in various countries to predict the mortality of non-surgical and trauma patients in the emergency department (ED) but has not been tested in a population-specific to head trauma. This study aimed to assess the performance of REMS in predicting the outcome of head trauma patients in ED. This study used analytic observation design with a retrospective approach. Samples that were based on medical records of patients with moderate-severe head trauma adjusted to inclusion and exclusion criteria and purposive sampling technique obtained a number of 181 respondents. Bivariate analysis conducted in this study used the Somers' D test, while multivariate analysis used ordinal logistic regression. Furthermore, the ability to predict outcomes was assessed using area under the receiver operating characteristic (AUROC) analysis. The bivariate test results show that the Somers' D REMS value was 0.310 with $p$-value $<0.001$ and a positive relationship with the outcome of head trauma patients. The ordinal logistic regression results showed that the Glasgow Coma Scale (GCS) parameter obtained an Odds Ratio of 0.7, meaning that a low GCS score had a risk of obtaining a death outcome of 0.7 times greater than obtaining a moderate disability, severe disability, and vegetative state. REMS Area Under Curve (AUC) values at the cut of point $>5$ with sensitivity 61.4 and specificity 77.8 were 0.753 (95\% Cl; 0.683-0,814). REMS shows a good performance in predicting the outcome of head trauma patients.

Keywords: Emergency departement, had injury, outcome, REMS

Korespondensi: Didik Mulyono. Program Studi Magister Keperawatan Fakultas Kedokteran Universitas Brawijaya Malang, Jl. Veteran 65145, Malang Tel.085232816599Email:mzdidik79@gmail.com

DOI: http://dx.doi.org/10.21776/ub.jkb.2019.030.04.13 


\section{PENDAHULUAN}

Trauma kepala merupakan penyebab kematian ketiga terbesar di dunia setelah penyakit kardiovaskuler dan neoplasma(1). Angka kejadian trauma kepala masih cukup tinggi, sekitar 100 hingga 200 per 100.000 orang dan diperkirakan akan menjadi penyebab utama kematian dan kecacatan pada tahun 2020 (2). Trauma kepala dianggap sebagai masalah kesehatan yang serius karena berdampak pada tingginya pembiayaan kesehatan dan kecacatan yang berakibat gangguan peran penderitanya di keluarga maupun masyarakat. Outcome pasien trauma tergantung pada tingkat keparahan, ketepatan penilaian awal dan waktu untuk mencapai tempat pertolongan perawatan. Penilaian yang cepat dan tepat dapat menurunkan angka kematian dan kecacatan jangka panjang (3).

Penilaian awal pasien dengan trauma merupakan hal yang berpengaruh pada penatalaksanaan pasien dengan trauma kepala. Mortalitas dapat menurun jika pasien trauma kepala segera dilakukan penilaian untuk mendapatkan penanganan yang tepat di rumah sakit. Penilaian awal yang hanya menggunakan Glasgow Coma Scale (GCS) untuk mengidentifikasi keparahan trauma kepala kurang memberikan hasil yang akurat, sehingga sering gagal mendeteksi risiko perburukan kondisi pada beberapa kelompok usia $(4,5)$. Dalam beberapa tahun terakhir, beberapa sistem scoring telah dikembangkan untuk menentukan apakah pasien membutuhkan perawatan intensif, pengobatan dan perawatan yang tepat(6). Sistem scoring juga dikembangkan untuk menilai tingkat keparahan pada pasien dengan trauma dan juga akan memberikan penilaian objektif terhadap kondisi klinis awal pasien sebagai bagian dari penentuan manajemen trauma(7).

Sistem skor Rapid Emergency Medicine Score (REMS) merupakan suatu sistem skor yang telah digunakan secara luas di berbagai negara untuk memprediksi mortalitas pasien yang datang ke Instalasi Gawat Darurat (IGD). Skor REM dihitung berdasarkan GCS, pernapasan, saturasi oksigen, Mean Arterial Pressure (MAP), nadi, dan usia (7). Skoring ini sudah terbukti menjadi penduga kematian yang mudah dan akurat di rumah sakit pada pasien trauma (8).

Penelitian yang dilakukan oleh Nakhjavan-Shahraki et al., menyebutkan bahwa REMS memiliki nilai prediktif sangat kuat terhadap mortalitas dan perburukan outcome pada pasien trauma yang datang ke IGD. Nilai Area Under Curve (AUC) dari REMS dalam memprediksi kematian di rumah sakit didapatkan 0,93 (95\% Cl: 0,92-0,95) (9). Hasil yang hampir sama juga didapatkan dari hasil penelitian Park et al., diskriminasi REMS pada pasien dengan trauma didapatkan nilai AUC sebesar 0,9, ini berarti bahwa REMS sangat baik memprediksi outcome pasien trauma (7).

Berbagai penelitian terkait validitas skor REMS pada populasi trauma telah banyak dilakukan. Meskipun demikian, penelitian tentang validitas REMS pada populasi yang spesifik terhadap pasien trauma kepala masih terbatas. Dalam beberapa penelitian sebelumnya pasien trauma yang datang ke IGD dengan gejala yang klinis bervariasi, baik gejala neourologis maupun fisiologis. Hal ini berbeda dengan pasien trauma kepala yang lebih menonjolkan gejala neurologis saat awal datang ke IGD dan sebagai standart baku penilaian awal menggunakan GCS (tingkat kesadaran). Skoring REMS dikembangkan sebagai assesment awal yang tidak hanya menilai pasien secara neurologis, tetapi mempertimbangkan aspek fisiologis dari pasien. Tujuan penelitian adalah mengetahui validitas scoring REMS dalam memprediksi outcome pasien dengan trauma kepala di IGD.

\section{METODE}

\section{Desain Penelitian}

Desain penelitian ini adalah observasional analitik dengan pendekatan kohort retrospektif. Pengambilan data dilakukan di ruang rekam medis RSUD dr. Soedono Madiun pada bulan Maret 2019. Instrumen penelitian yang digunakan dalam penelitian ini adalah lembar catatan karakteristik responden dan lembar catatan berdasarkan parameter REMS meliputi GCS, pernapasan, saturasi oksigen, MAP, nadi dan usia. Outcome pasien cedera kepala diukur menggunakan lembar catatan Glasgow Outcome Scale atau GOS. Penelitian ini telah mendapat persetujuan etik dari Komisi Etik Penelitian Kesehatan Fakultas Kedokteran Universitas Brawijaya dengan nomor: 89/EC/KEPK-S2/03/2019 dan surat izin penelitian dari bagian penelitian RSUD dr. Soedono Madiun dengan nomor: 070/6909/303/2019.

\section{Populasi Penelitian}

Populasi penelitian ini adalah pasien yang datang ke IGD RSUD dr. Soedono Madiun pada rentang waktu bulan Januari Tahun 2016 sampai dengan bulan Desember tahun 2018. Sampel penelitian ini sebanyak 181 rekam medis yang memenuhi kriteria inklusi dan eksklusi. Kriteria inklusinya adalah pasien trauma kepala sedang-berat yang berkunjung ke IGD berusia $\geq 16$ tahun dan terdapat hasil pengukuran nadi, respirasi, saturasi oksigen, usia, MAP dan GCS di rekam medis. Pasien hamil, pasien berumur kurang dari 16 tahun, pasien trauma kepala rujukan, pasien dengan Penyakit Paru Obstruktif Kronik (PPOK), luka bakar, dan tenggelam tidak disertakan dalam penelitian.

\section{Pengumpulan dan Penghitungan Data}

Data yang dikumpulkan meliputi usia, jenis kelamin, pendidikan, pekerjaan, penyebab trauma kepala, parameter REMS maupun outcome pasien trauma kepala. Dalam perhitungan REMS, usia diberi nilai dari 0 hingga 6 , dan lima parameter sisanya masing-masing diberi skor dari 0 hingga 4 (Tabel 1). Skor REMS berkisar antara 0-26, skor $<5$ dinilai sebagai risiko rendah, antara 5-13 dinilai risiko sedang dan $>13$ dinilai risiko tinggi. Sedangkan outcome di evaluasi pada saat pasien keluar dari rumah sakit dihitung menggunakan Glasgow Outcome Scale atau GOS. Hasil penghitungan outcome pasien trauma kepala berdasarkan GOS dengan 5 kategori yaitu good recovery, moderate disable, severe disable, vegetative, dan death. Outcome dikatakan baik jika pasien pada kategori good recovery dan moderate disable, sedangkan outcome buruk jika pada kategori severe disable, vegetatif dan death(9).

\section{Analisis Statistik}

Data di analisis dengan bantuan Software SPSS for Windows Versi 20 dan Medcalc. Data kategorikal disajikan dalam persentase dan data kontinu dengan median dan kuartil. Analisis bivariat menggunakan uji Somers'd untuk menguji REMS dengan outcome pasien trauma kepala. Analisis multivariat menggunakan uji regresi ordinal untuk mengetahui parameter REMS yang paling dominan mempengaruhi outcome pasien trauma kepala. The area 
under the receiver operating characteristic (AUROC) digunakan untuk menilai kemampuan REMS membedakan outcome baik dan outcome buruk. Selain itu, nilai Area Under Curve (AUC), tingkat sensitivitas, spesifisitas dan akurasi dihitung berdasarkan cut of point optimal yang berasal dari analisis AUROC.

Tabel 1. Rapid Emergency Medicine Score (REMS) scoring system

\begin{tabular}{|c|c|c|c|c|c|c|c|}
\hline \multirow{2}{*}{ Variable } & \multicolumn{7}{|c|}{ Score } \\
\hline & 0 & 1 & 2 & 3 & 4 & 5 & 6 \\
\hline Age (Year) & $<45$ & & $45-54$ & 55-64 & & $65-74$ & $>74$ \\
\hline $\mathrm{PR} / / \mathrm{min})$ & $70-109$ & & $55-69$ & $40-54$ & $\leq 39$ & & \\
\hline $\mathrm{PR}(/ \mathrm{min})$ & $10-109$ & & $110-139$ & $140-179$ & $>179$ & & \\
\hline $\mathrm{MAP}(\mathrm{mmHg})$ & $70-109$ & & $\begin{array}{r}50-69 \\
110-129\end{array}$ & $130-159$ & $\begin{array}{r}\leq 49 \\
>159\end{array}$ & & \\
\hline $\mathrm{RR}(/ \mathrm{min})$ & $12-24$ & $\begin{array}{l}10-11 \\
25-34\end{array}$ & $6-9$ & $35-49$ & $\begin{array}{r}\leq 5 \\
>49\end{array}$ & & \\
\hline GCS & 14 or 15 & $11-13$ & $8-10$ & $5-7$ & 3 or 4 & & \\
\hline $\mathrm{SpO} 2(\%)$ & $>89$ & $86-89$ & & $75-85$ & $<75$ & & \\
\hline
\end{tabular}

Keterangan: PR: Pulse Rate; MAP: Mean Arterial Pressure; RR: Respirasi Rate; GCS: Glasgow Coma Scale; SpO2; peripheral oxygen saturation. Sumber: Olsson et al. (10).

\section{HASIL}

\section{Karakteristik Subjek}

Tabel 2 menunjukkan sebagian besar sample berjenis kelamin laki-laki (128, 71\%). Berdasarkan karakteristik usia, usia responden terbanyak (23\%) adalah kelompok usia 16-26 tahun. Hampir setengah responden (40\%) dengan tingkat pendidikan SLTA. Pekerjaan responden sebanyak $36 \%$ dari total responden adalah karyawan swasta. Penyebab trauma kepala, hampir seluruhnya yakni $86 \%$ adalah kecelakaan lalu lintas.

Tabel 2. Karakteristik subjek penelitian

\begin{tabular}{llcc}
\hline Variabel & Klasifikasi & N & $\%$ \\
\hline Jenis Kelamin & Laki-Laki & 128 & 7 \\
& Perempuan & 53 & 2 \\
& & & 9 \\
Usia & $16-25$ & 41 & 2 \\
& & & 3 \\
& $26-35$ & 21 & 1 \\
& $36-45$ & 20 & 1 \\
& & & 1 \\
\hline
\end{tabular}

Tabel 2. Karakteristik subjek penelitian (Lanjutan)

\begin{tabular}{|c|c|c|c|c|}
\hline Variabel & & Klasifikasi & $\mathbf{N}$ & $\%$ \\
\hline \multirow[t]{4}{*}{ Usia } & & $46-55$ & 37 & 2 \\
\hline & & $56-65$ & 36 & 2 \\
\hline & & & 36 & 0 \\
\hline & & $>65$ & 26 & 1 \\
\hline \multirow{7}{*}{\multicolumn{2}{|c|}{ Pendidikan }} & Tidak Sekolah & 1 & 1 \\
\hline & & SD & 71 & 3 \\
\hline & & SLTP & 25 & 1 \\
\hline & & SLTA & & 4 \\
\hline & & & 12 & 0 \\
\hline & & PT & 12 & 7 \\
\hline & & Tidak Bekerja & 19 & 1 \\
\hline \multirow[t]{8}{*}{ Pekerjaan } & & Pedagang & 4 & 2 \\
\hline & & Karyawan Swasta & 66 & 3 \\
\hline & & & & 6 \\
\hline & & Wiraswasta & 8 & 4 \\
\hline & & Petani & 45 & $\begin{array}{l}2 \\
5\end{array}$ \\
\hline & & PNS/TNI/POLRI & 9 & 5 \\
\hline & & Pelajar/Mahasiswa & 30 & 1 \\
\hline & & & & 7 \\
\hline Penyebab & Trauma & Kecelakaan Lalu Lintas & 155 & 86 \\
\hline Kepala & & Terjatuh & 26 & 14 \\
\hline
\end{tabular}

Hubungan Skoring REMS dengan Outcome Pasien Trauma Kepala

Tabel 3 menunjukkan bahwa responden yang memiliki risiko sedang sebesar 64 juga memperoleh outcome meninggal (death). Hasil uji Somers'd terlihat bahwa nilai signifikansi adalah 0,000. Hasil uji Somers'd=0,310, nilai ini menunjukkan tingkat hubungan antar variabel terbilang sedang. Arah hubungan yang positif ini berarti bahwa tingginya scoring REMS diikuti dengan perburukan outcome pasien trauma kepala.

\section{Analisis Multivariat Parameter Skoring REMS}

Tabel 4 menunjukkan bahwa dari enam parameter yang diduga mempengaruhi outcome pasien trauma kepala, terdapat dua parameter yang memiliki nilai p-value kurang dari 0,05 yaitu umur dan Skor GCS. Odds ratio parameter GCS sebesar 0,7 , artinya skor GCS yang rendah memiliki risiko memperoleh outcome death sebesar 0,7 kali lebih besar dibandingkan memperoleh outcome moderate disability, severe disability, persisten vegetatifve state.

Tabel 3. Analisis hubungan scoring REMS dengan outcome pasien trauma kepala

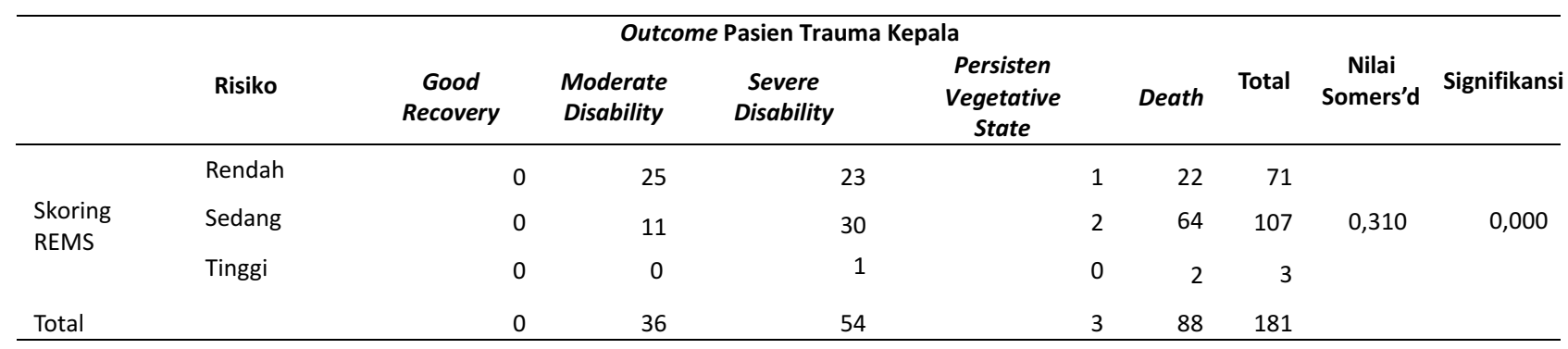


Tabel 4. Uji multivariat regeresi ordinal

\begin{tabular}{lcccc}
\hline Variabel & Estimate & Uji Wald & p-value & Odd Ratio \\
\hline Umur & 0,027 & 9,532 & 0,002 & 1,03 \\
Nadi & 0,007 & 0,698 & 0,403 & \\
MAP & 0,004 & 0,189 & 0,664 & \\
Respirasi & 0,031 & 1,377 & 0,241 & \\
Skor GCS & $-0,388$ & 33,318 & 0,000 & 0,7 \\
SpO2 & $-0,071$ & 0,993 & 0,319 & \\
\hline
\end{tabular}

Analisis Kurva ROC untuk Menentukan Nilai AUC, Cut of Point, Sensitivitas, Spesifisitas dan Akurasi

Gambar 1 menunjukkan kurva ROC yang dihasilkan dari berbagai nilai cut of point yang menunjukkan kurva ROC berada di atas garis referensi. Nilai AUC yang dihasilkan yaitu sebesar $0,753(95 \% \mathrm{Cl} ; 0,683-0,814)$ sehingga berdasarkan nilai AUC tersebut tingkat ketepatan prediksi scoring REMS pada klasifikasi baik. Pada cut of point optimal yaitu $>5$, nilai sensitivitas REMS terhadap outcome pasien trauma kepala sebesar $61,38 \%$ dan spesifisitas sebesar $77,78 \%$. Dengan menggunakan cut of point $>5$ didapatkan nilai akurasi sebesar $70 \%$, Predictive Positif Value sebesar 91,8 \%, Negatif Predictive Value sebesar 33,3\%.

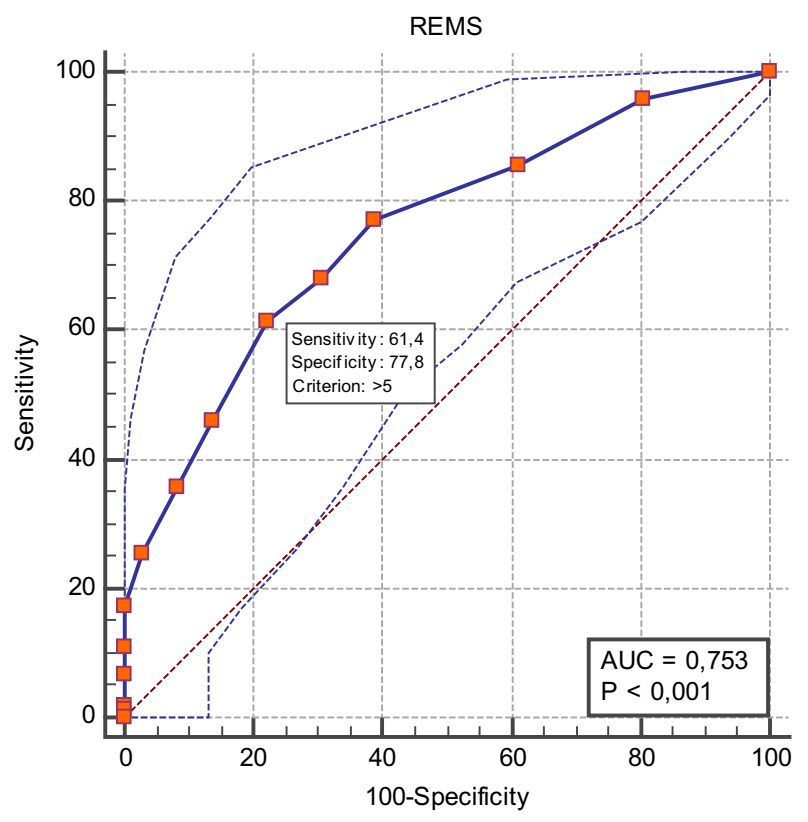

Gambar 1. Grafik ROC scoring MEWS

\section{DISKUSI}

Karakteristik Subjek Penelitian

Berdasarkan hasil penelitian didapatkan hampir seluruhnya responden yaitu $128(71 \%)$ adalah berjenis kelamin laki-laki. Hasil ini hampir sama dengan penelitian yang dilakukan oleh Hartoyo, Raharjo, \& Budiyati, didapatkan $75,4 \%$ responden berjenis kelamin laki-laki (11). Sesuai dengan data dari National and International Epidemiological yang menyebutkan bahwa trauma kepala akan memengaruhi kesehatan terutama yang berjenis kelamin laki-laki. Perbandingan kejadian trauma kepala antara laki-laki dengan perempuan dengan proporsi 4:1 (12). Faktor yang mungkin menjadi penyebab tingginya trauma kepala sedang-berat pada laki-laki di antaranya adalah aktivitas fisik maupun pekerjaan yang lebih berisiko dari perempuan. Meskipun demikian menurut Marcolini, Albrecht, Sethuraman, \& Napolitano, tingginya kejadian trauma kepala pada laki-laki bukan hanya karena aktivitas fisik dan pekerjaan saja, ada faktor hormonal pada laki-laki yang akan memicu stres dan mengakibatkan perilaku berisiko terjadinya trauma kepala seperti minum alkohol saat mengendarai kendaraan bermotor(13).

Hasil penelitian ini menunjukkan bahwa trauma kepala sedang-berat paling banyak dialami oleh kelompok usia 16-25 tahun. Hasil penelitian ini juga didapatkan usia paling tinggi 118 tahun dan paling rendah 16 tahun. Temuan ini sesuai dengan hasil temuan penelitian sebelumnya yang menunjukkan kelompok usia 15-24 tahun merupakan kelompok terbanyak mengalami trauma kepala, di mana kelompok ini merupakan kelompok dewasa muda yang memiliki produktivitas dan aktivitas yang tinggi (14). Kecelakaan kendaraan bermotor adalah penyebab trauma kepala paling umum pada kelompok umur 15-19 tahun dan 20-24 tahun (15). Tingginya angka kejadian trauma kepala pada kelompok usia ini akibat kecelakaan lalu lintas dimungkinkan oleh karena tingginya mobilitas dan perkembangan psikologis, di mana usia dewasa muda perkembangan psikologis yang belum stabil sehingga sering gagal mengendalikan emosi. Keadaan ini menyebabkan kewaspadaan yang kurang dalam mengemudikan kendaraan bermotor.

Berdasarkan jenis pekerjaan, dalam penelitian ini didapatkan pekerjaan terbanyak adalah karyawan swasta sejumlah 66 responden (36\%). Hasil penelitian ini agak berbeda dengan hasil penelitian oleh Krisandi, Utomo, dan Indriati, bahwa jenis pekerjaan responden trauma kepala adalah pelajar/mahasiswa (16). Dari hasil penelitian dan fakta penelitian sebelumnya dapat di asumsikan bahwa jenis pekerjaan mempunyai keterkaitan dengan kejadian trauma kepala, hal ini bisa dilihat dari faktor penyebab trauma kepala pada penelitian ini terbanyak adalah kecelakaan lalu lintas (86\%). Dari data yang diperoleh, peneliti mengasumsikan bahwa semakin sering pekerjaan yang membutuhkan aktivitas di jalan seperti mengendarai sepeda motor, mobil, becak maupun pejalan kaki semakin tinggi pula kemungkinan terjadinya trauma kepala.

Hubungan Skoring REMS dengan Outcome Pasien Trauma Kepala

Hasil tabulasi silang antara scoring REMS dengan outcome pasien trauma kepala didapatkan hasil bahwa responden dengan skor REMS risiko sedang juga mendapatkan outcome meninggal (death) sebanyak 64 (60\%) responden. Hasil analisis bivariat menggunakan uji Somers'd didapatkan bahwa $p$ value sebesar 0,000 , yang menunjukkan kekuatan hubungan sedang antara scoring REMS dengan outcome pasien trauma kepala. Artinya semakin tinggi scoring REMS yang diperoleh semakin buruk outcome pasien trauma kepala.

Hasil tersebut sesuai dengan hasil penelitian oleh Imhoff et al., yang menyatakan bahwa terdapat hubungan scoring REMS dengan mortalitas di rumah sakit pada populasi trauma. Setiap peningkatan 1 poin scoring REMS dikaitkan dengan peningkatan mortalitas di rumah sakit. Meskipun awalnya Skoring REMS tidak dirancang untuk populasi trauma, namun scoring REMS ditemukan sebagai prediktor kuat mortalitas di rumah sakit untuk populasi trauma. REMS memiliki kinerja yang mirip dengan Revised 
Trauma Score (RTS) dan mengungguli beberapa scoring trauma yang digunakan sebelumnya seperti Injury Severity Score (ISS) dan Shock Indeks (SI) (8). Hasil yang sama juga ditunjukkan dari hasil penelitian yang dilakukan oleh Alter, Infinger, Swanson, dan Studnek, bahwa scoring REMS berkorelasi dengan angka morbiditas dan mortalitas (17). Berdasarkan hasil penelitian ini, scoring REMS berguna dalam mengevaluasi perubahan klinis pasien di IGD, karena terdapat hubungan yang bermakna antara scoring REMS dengan outcome pasien trauma kepala.

Adanya kesamaan hasil dengan penelitian ini dengan sebelumnya dimungkinkan karena populasi responden yang digunakan hampir sama yaitu pasien trauma. Walaupun pada penelitian ini lebih fokus pada trauma kepala, namun dimungkinkan tak ada perbedaan yang berarti hasil pengukuran parameter scoring REMS di antara pasien akibat trauma. Meskipun terdapat perbedaan metode yang digunakan antara penelitian ini dengan kedua penelitian sebelumnya namun tidak memberikan perbedaan hasil yang signifikan. Hal ini mengindikasikan tingkat akurasi yang tinggi pengukuran parameter dalam scoring REMS saat pasien masuk IGD.

Parameter REMS Paling Dominan Mempengaruhi Outcome Pasien Trauma Kepala

Hasil uji multivariat dari masing-masing parameter scoring REMS menggunakan uji regresi ordinal didapatkan 2 parameter yang berpengaruh secara signifikan terhadap outcome pasien trauma kepala yaitu usia dan skor GCS dengan skor GCS sebagai prediktor yang paling dominan. Pasien dengan skor GCS yang rendah memiliki risiko memperoleh outcome death sebesar 0,7 kali lebih besar dibandingkan memperoleh outcome moderate disability, severe disability, persistent vegetative state.

Hasil uji multivariat ini tidak berbeda dari hasil yang dilakukan oleh Imhoff et al., yang menyebutkan bahwa usia dan skor GCS memiliki kontribusi yang signifikan secara statistik dalam prediksi kematian, sementara nadi dan respirasi tidak memiliki kontribusi signifikan secara statistik terhadap prediksi kematian (8). GCS merupakan alat ukur paling umum digunakan untuk mendeteksi keparahan trauma kepala dan menjadi alat prognosis untuk pasien yang mengalami trauma kepala -(18). Skor awal GCS memiliki korelasi yang signifikan dengan outcome pasien trauma kepala (19). Skor GCS yang rendah saat masuk IGD dikaitkan dengan outcome yang buruk. Skor GCS saat masuk IGD merupakan prediktor independen yang signifikan terhadap outcome pasien trauma kepala dan Skor GCS telah terbukti menunjukkan tingkat keparahan trauma kepala (20). Skor GCS memberikan informasi tentang status neurologis pasien dan merupakan elemen evaluasi perkembangan kondisi klinis pasien trauma kepala. GCS diperkenalkan pada tahun 1974 dengan tujuan menstandarkan penilaian tingkat kesadaran pada pasien yang mengalami trauma kepala. Meskipun demikian, temuan dari penelitian menunjukkan bahwa ada 4 responden dengan skor GCS awal rendah (3-8) memperoleh outcome baik. Hal ini dimungkinkan karena adanya faktor lain seperti usia, mekanisme cedera dan tersedianya pelayanan yang cepat dan tepat sehingga terhindar dari cedera sekunder maupun kematian. Penggunaan usia pada scoring REMS sebagai salah satu parameter terbukti memberikan nilai prediktif yang lebih baik. Hasil uji multivariat menunjukkan bahwa usia berpengaruh signifikan terhadap outcome pasien trauma kepala dengan nilai OR sebesar 1,03, artinya setiap penambahan usia 1 tahun memiliki risiko memperoleh outcome death sebesar 1,03 kali lebih besar dibandingkan memperoleh outcome moderate disability, severe disability, persisten vegetatif state. Meskipun demikian, diperlukan parameter lain selain yang tercakup pada scoring REMS agar memberikan nilai prediktif yang lebih baik lagi seperti mekanisme cedera, tekanan darah, dan lama prehosital.

\section{Performa Kalibrasi dan Diskriminasi REMS terhadap Outcome Pasien Trauma Kepala}

Berdasarkan grafik ROC menunjukkan REMS memiliki performa yang baik untuk prediksi outcome trauma kepala di IGD dengan nilai AUC di 0,753. Hasil ini hampir sama dengan penelitian sebelumnya yang menunjukkan performa baik bahkan sangat baik. Imhoff et al., yang meneliti scoring REMS untuk prediksi mortalitas pada populasi trauma menemukan nilai AUC 0,91 atau performa baik, Nakhjavan-shahraki et al., yang juga meneliti scoring REMS untuk prediksi outcome pada populasi trauma menemukan nilai AUC 0,92 atau performa sangat baik (9). Nilai ini berbeda dengan hasil penelitian Hung et al., yang memprediksi mortalitas pasien sepsis di IGD mendapatkan AUC sebesar 0,67 atau performa cukup(21).

Perbedaan berbagai penelitian dimungkinkan karena perbedaan dalam metode penelitian yang meliputi desain, populasi maupun tempat penelitian. Menurut NakhjavanShahraki et al., sistem scoring dikembangkan dan difungsikan sesuai dengan kondisi klinis pasien, yang meliputi: sistem fisiologis, anatomi maupun trauma. Dari hasil penelitian dan teori yang disajikan dapat disimpulkan bahwa ketepatan metode penelitian dan sistem scoring dimungkinkan akan meningkatkan nilai prediktif sistem scoring yang diteliti(9).

Nilai cut off point optimal $>5$ (risiko sedang) digunakan untuk memprediksi outcome pasien trauma kepala di IGD dengan sensitivitas $61,38 \%$, spesifisitas, $77,78 \%$. Hasil ini hampir sama dengan hasil penelitian oleh Park et al., yang memperoleh cut off point optimal 7 (risiko sedang) dengan sensitivitas $84,4 \%$, spesifisitas $77,3 \%$ (7), juga Hung et al., memperoleh nilai cut off point optimal 7 (risiko sedang) dengan sensitivitas $64,29 \%$, spesifisitas $72 \%$ (21). Adanya kemiripan nilai cut off point optimal yang diduga skor awal berisiko dan berdampak pada outcome yang buruk ini menunjukkan bahwa parameter REMS mampu memprediksi outcome pasien trauma kepala pada semua penelitian. Uji sensitivitas, spesifisitas, dan akurasi dilakukan untuk mengukur kemampuan scoring REMS dalam mendeteksi outcome pasien trauma kepala. Nilai sensitivitas scoring REMS sebesar $61,38 \%$, artinya kemampuan scoring REMS mendapat outcome buruk pada pasien trauma kepala yang berisiko sedang-tinggi sebesar $61,38 \%$. Nilai spesifisitas scoring REMS sebesar $77,78 \%$, berarti kemampuan scoring REMS mendapat outcome baik pada pasien trauma kepala yang berisiko ringan sebesar $77,78 \%$. Akurasi scoring REMS sebesar 70\%, berarti bahwa kemampuan scoring REMS untuk mendeteksi secara benar subjek yang diuji sebesar $70 \%$.

Penilaian awal pasien trauma kepala merupakan hal penting dalam penentuan derajat maupun tindakan yang harus segera diberikan sesuai dengan tingkat kegawatan. Hasil penelitian ini memperlihatkan bahwa scoring REMS menunjukkan performa yang baik terhadap risiko dan outcome pada pasien dengan trauma kepala. Hal ini 
mengandung implikasi agar ke depannya dalam menentukan derajat pasien trauma kepala tidak hanya berdasarkan status neurologis (tingkat kesadaran) akan tetapi perlu mempertimbangkan penggunaan sistem scoring yang telah banyak dikembangkan akhir-akhir ini. Meski demikian, penelitian ini juga memiliki beberapa keterbatasan, yaitu pertama jumlah sampel yang kecil dan penggunaan data sekunder dengan rekam medis adalah jumlah data yang ditemukan tidak menyeluruh dan mungkin ada data yang hilang saat penyimpanan kedua

\section{DAFTAR PUSTAKA}

1. Weber KT, Guimarães VA, Pontes-Neto OM, Leite JP, Takayanagui OM, and Santos-Pontelli TEG. Preditores De Qualidade De Vida Após Trauma CrâNio-Encefálico Moderado A Grave. Arquivos de Neuro-Psiquiatria. 2016; 74(5): 409-415.

2. Venturini S, Still MEH, Vycheth I, Nang S, Vuthy D, and Park KB. The National Motorcycle Helmet Law at 2 Years: Review of Its Impact on the Epidemiology of Traumatic Brain Injury in a Major Government Hospital in Cambodia. World Neurosurgery. 2019; 125: 320-326.

3. Miller RT, Nazir N, McDonald T, and Cannon CM. The Modified Rapid Emergency Medicine Score: A Novel Trauma Triage Tool To Predict In-Hospital Mortality. Injury. 2017; 48(9): 1870-1877.

4. Scheetz LJ, Horst MA, and Arbour RB. Early Neurological Deterioration in Older Adults with Traumatic Brain Injury. International Emergency Nursing. 2018; 37: 29-34.

5. Najafi Z, Zakeri H, and Mirhaghi A. The Accuracy of Acuity Scoring Tools to Predict 24-H Mortality in Traumatic Brain Injury Patients: A Guide to Triage Criteria. International Emergency Nursing. 2018; 36: 27-33.

6. Gök RGY, Gök A, and Bulut M. Assessing Prognosis with Modified Early Warning Score, Rapid Emergency Medicine Score and Worthing Physiological Scoring System in Patients Admitted to Intensive Care Unit from Emergency Department. International Emergency Nursing. 2019; 43: 9-14.

7. Park HO, Kim JW, Kim SH, et al. Usability Verification of the Emergency Trauma Score (EMTRAS) and Rapid Emergency Medicine Score (REMS) in Patients with Trauma: A Retrospective Cohort Study. Medicine. 2017; 96(44):1-5.

8. Imhoff BF, Thompson NJ, Hastings MA, Nazir N, Moncure M, and Cannon CM. Rapid Emergency Medicine Score (REMS) in the Trauma Population: A Retrospective Study. BMJ Open. 2014; 4(5): 1-7.

9. Nakhjavan-shahraki B, Baikpour M, Yousefifard M, et al. Rapid Acute Physiology Score Versus Rapid Emergency Medicine Score in Trauma Outcome Prediction; A Comparative Study. Emergency. 2017; 5(1): 165-172.

10. Olsson T, Terent A, and Lind L. Rapid Emergency Medicine Score Can Predict Long-Term Mortality in Nonsurgical Emergency Department Patients. Academic Emergency Medicine. 2004; 11(10): 1008-1013. penggunaan hanya satu tempat penelitian rumah sakit juga dimungkinkan hasil penelitian ini tidak bisa menggambarkan target populasi yaitu pasien trauma kepala yang datang ke IGD di Indonesia.

Kesimpulan yang diperoleh dari penelitian adalah kemampuan scoring REMS memprediksi outcome pasien trauma kepala menunjukkan performa baik, sehingga perlu dipertimbangkan penggunaan scoring REMS sebagai salah satu sistem deteksi dini atau Early Warning Score Sistem (EWSS) di rumah sakit khususnya di IGD.

11. Hartoyo M, Raharjo SS, and Budiyati. Predictor ' S Factors of Mortality of Patients Suffering from Severe Head Injury in Emergency Department at General Hospital Tugurejo Semarang. Jurnal Riset Kesehatan. 2012; 1(3): 175-182.

12. Oliveira RA, Araújo S, and Falcão AL. Glasgow Outcome Scale at Hospital Discharge as a Prognostic Index in Patients with Severe Traumatic Brain Injury. Arquivos de Neuro-Psiquiatria. 2012; 70(8): 604-608.

13. Marcolini EG, Albrecht JS, Sethuraman KN, and Napolitano LM. Gender Disparities in Trauma Care: How Sex Determines Treatment, Behavior, and Outcome. Anesthesiology Clinics. 2019; 37(1): 107117.

14. Lisnawati, Kwandou L, Akbar M, Muis A, Kaelan C, and Patellongi I. Hubungan Skor Cognitive Test for Delirium (CTD) dengan Luaran Berdasarkan Glasgow Outcome Scale (GOS) pada Penderita Cedera Kepala Tertutup Ringan-Sedang. Jurnal Sains \& Teknologi Kesehatan. 2012; 2(2): 163-170.

15. Peeters W, van den Brande R, Polinder S, et al. Epidemiology of Traumatic Brain Injury in Europe. Acta Neurochirurgica. 2015; 157(10): 1683-1696.

16. Krisandi E, Utomo W, dan Indriati G. Gambaran Status Kognitif pada Pasien Cedera Kepala yang Telah Di Izinkan Pulang Di RSUD Arifin Achmad Pekanbaru. [Repository]. Universitas Riau, Riau. 2013.

17. Alter SM, Infinger A, Swanson D, and Studnek JR. Evaluating Clinical Care in the Prehospital Setting: Is Rapid Emergency Medicine Score the Missing Metric of EMS? The American Journal of Emergency Medicine. 2017; 35(2): 218-221.

18. Lee YS, Choi JW, Park YH, et al. Evaluation of the Efficacy of the National Early Warning Score in Predicting in-Hospital Mortality Via the Risk Stratification. Journal of Critical Care. 2018; 47: 222226.

19. Suwaryo PAW, Wihastuti TA, dan Fathoni M. Analisis Faktor-faktor yang Berhubungan dengan Outcome Pasien Cedera Kepala di IGD RSUD Prof. Dr. Margono Soekardjo Purwoerto. Jurnal IImiah Kesehatan Keperawatan. 2016; 12(3): 154-164.

20. Khan KA, Choudhary M, Sinha VD, Gora N, and Bairwa M. Predictors of Outcome after Traumatic Brain Injuries: Experience of a Tertiary Health Care Institution in Northwest India. World Neurosurgery. 2019; 126: 699-705.

21. Seak CJ, Yen DHT, Ng CJ, et al. Rapid Emergency 
Medicine Score: A Novel Prognostic Tool for Predicting the Outcomes of Adult Patients with
Hepatic Portal Venous Gas in the Emergency Department. PLoS One. 2017; 12(9): 1-9. 